\title{
Effect of Dietary Pumpkin Stem Waste on Haematological Indices, Meat and Serum Lipid Profiles of Rabbits
}

\author{
J. S. Ekpo, \\ Department of Animal Science, \\ Akwa Ibom State University, Nigeria \\ N. J. Okeudo, \\ M. C. Uchegbu, \\ E. B. Etuk, \\ Department of Animal Science and Technology, \\ Federal University of Technology, Owerri, Nigeria
}

URL:http://dx.doi.org/10.19044/esj.2019.v15n6p10

\begin{abstract}
This study evaluated the effect of different supplementary dietary levels of pumpkin stem waste (PSW) on the haematological indices, meat and serum lipid profile of rabbits. Three experimental feed regime: $\mathrm{D}_{1}$ (control), basal feed $+0 \%$ PSW $; \mathrm{D}_{2}$, basal feed $+5 \%$ PSW and $\mathrm{D}_{3}$, basal feed $+10 \%$ PSW were randomly assigned to the three treatment groups in a $3 \times 2$ factorial arrangement in a completely randomized design experiment. The PSW percentage were offered on rabbit weight basis. Thirty six (18 males and 18 females) crossbred (California x New Zealand white) weaned rabbits aged 6 and 7 weeks were divided into three treatment groups of 12 rabbits each with 4 rabbits per replicate ( 2 females and 2 males) and randomly allotted to the three dietary treatments. At the end of 12 weeks feeding trial( prior to slaughtering), blood samples were collected from 6 rabbits ( 3 males and 3 females) per treatment totalling 18 rabbits and used to determine the serum lipid profile and haematological blood indices. Similarly, breast meat sample was used to determined lipid profile. Results obtained showed that while red blood cell (RBC), haemoglobin (Hb), packed cell volume (PCV), Mean cell haemoglobin $(\mathrm{MCH})$ and mean cell haemoglobin concentration $\mathrm{MCHC}$ increased $(\mathrm{P}<0.05)$ with increasing dietary PSW. White blood cell $(\mathrm{WBC})$ and MCHC however showed no significant difference $(\mathrm{P}>0.05)$ among the treatments groups. Lipid profile of both serum and meat indicated that HDL increased significantly $(\mathrm{P}<0.05)$ with increase in PSW while total cholesterol (TC), low density lipoprotein (LDL), triglyceride (TG) and very low density
\end{abstract}


lipoprotein (VLDL) decreased significantly $(\mathrm{P}<0.05)$. Diet by sex interaction showed that male rabbits recorded significantly different $(\mathrm{P}<0.05)$ values from their female counterparts in all the blood and meat lipid parameters assessed. These results suggest that pumpkin stem waste is hypolipidaemic therefore could lower rabbits' meat cholesterol and improve blood constituents.

Keywords: Rabbit, meat, serum, lipid, haematology, pumpkin stem

\section{Introduction}

One of the advantages of rabbit production in tropical countries is that rabbits can be fed forages and agricultural by-products such as yam peels, cassava peels and pumpkin stem waste which are not suitable for human consumption (Ekpo et al., 2015 and Ekpo et al., 2016) characteristically have small body size, short generation interval, high reproductive potential, rapid growth rate, high efficiency in converting forage and fibrous agricultural byproducts to meat. This makes rabbits particularly suitable as meat producing small livestock in Nigeria. Despite being less efficient as ruminants in digesting fiber components of the diet, Rabbit seem not to perform better in diets containing crude fiber above 15\% (Iyeghe-Erakpotobor and Muhammad, 2008; Cheek and Patton, 1985) yet fibrous agricultural by-products are essential to rabbits not only for their roughage but also for growth enhancement especially when combined with concentrate (Ekpo et al, 2008). Increased awareness in developing countries about the nutritional quality and need for healthy eating habit make consumers to reduce meat consumption due to the fear of hypercholesterolemia (Abeywardena, 2003). Cholesterol which is transported in the blood stream in large molecules of fat and protein called lipoproteins exist as chylomicrons, very low density lipoproteins, lowdensity lipoproteins (LDL) and high density lipoprotein (HDL). A high level of LDL in the blood increases the risk of fat deposits formation in the arteries causing arteriosclerosis. This in turn increases the risk of heart attack. On the other hand, an elevated level of HDL seems to have a protective effect against arteriosclerosis by reducing the cholesterol pool that may deposit on arterial walls (Durrington et al., 1988). Since the level and type of fat are the main dietary factors that affect quality of rabbit carcasses and meat, there is the need therefore, to adopt measures to produce meat with low cholesterol level. One way of lowering meat cholesterol levels is to incorporate cholesterol-reducing factors into the diets of meat producing animals (Jayaweera et al., 2007). Dietary inclusion of certain crops residues which are suspected to have therapeutic values in diets may achieve these purposes. Inclusion of pumpkin leaf extract in rat diets have been reported to alter lipid profile (Ugwu et al., 2011). This study therefore aimed at evaluating the effect of pumpkin stem 
waste on meat and serum lipid profile as well as blood parameters of male and female rabbits.

\section{Materials and Methods Study location}

This study was conducted at the Teaching and Research livestock Farm of Akwa Ibom State University, Obio Akpa Campus in the South Eastern Agro-ecological zone, Nigeria. Akwa Ibom State lying, $70 \mathrm{~m}$ above sea level, located between latitude $4^{\circ} 58^{\prime}$ and $5^{\circ} 08^{\prime} \mathrm{N}$ and longitude $8^{\circ} 02^{\prime}$ and $9^{\circ} 47^{\prime} \mathrm{E}$, temperature range between $25^{\circ} \mathrm{C}$ and $26^{\circ} \mathrm{C}$ with average relative humidity of $75-80 \%$ while mean annual rainfall vary from $2250 \mathrm{~mm}$ to $2926 \mathrm{~mm}$ in a year (SLUS-AK,1994).

Sample of PSW was subjected to proximate analysis according to AOAC (1990). Phytochemical tests of the spices in terms of flavonoids, saponins, phenols, glycoside and Alkaloid were carried out using standard procedures as described by Harborne (1973) and enunciated by Trease and Evans (2002) while mineral and vitamins were determine according to Lorenz (1982). The laboratory analysis was carried out at the Animal Science laboratory of the Akwa Ibom State University, Nigeria.

\section{Experimental Diets, Animals and Design}

Pumpkin stem wastes were collected daily from the vegetable farm of the Faculty of Agriculture, Akwa Ibom state University .These stems were washed and chopped $(5-7 \mathrm{~cm})$ using sharp knife. Samples of the fresh pumpkin stem were was analysed initially to determine its proximate, minerals and vitamins composition using standard procedures according to AOAC (1990). Thereafter grower diet for the rabbit was formulated and offered to rabbits in all the test group as follows: basal feed with 0\% PSW (D1); basal feed with 5\% PSW (D2); basal feed with 10\% PSW (D3) before offered to all rabbits. The three graded levels $(0 \%, 5 \%$ and $10 \%$ according to body weight of the rabbit) of pumpkin stem waste (PSW) given represented three dietary treatments. Thirty six (18 males and 18 females) crossbred (California $\mathrm{x}$ Chinchilla) weaned rabbits aged 6 and 7 weeks weighing $650 \mathrm{~g}-690 \mathrm{~g}$ were acquired from the same University livestock and research farm. The rabbits were initially preconditioned for two weeks to enhance feeding adjustment and deworming before allotted equally (12 rabbits) on weight equalization basis to each of the three treatments groups. Each treatment group was subdivided into 3 replicates comprising 4 rabbits per replicate ( 2 males and 2 females). Each set of sex (male or female) in the replicate was housed in a hutch measuring $70 \mathrm{~cm} \times 40 \mathrm{~cm}$. The entire hutch system was of the three-tier model. Experimental diet were randomly allotted to the three experimental rabbit group as follows: $\mathrm{D}_{1}$ (basal feed $+0 \%$ PSW) which served as control, D2 
(basal feed $+5 \%$ PSW), $\mathrm{D}_{3}$ (basal feed $+10 \%$ PSW) in a $3 \times 2$ factorial arrangement. The percentage level of PSW were based on the average liveweight of the rabbit. Feed and water were offered ad libitum twice daily for 84 days.

Lipid profile and Haematological determination: On the $84^{\text {th }}$ day of the feeding trial, $10 \mathrm{ml}$ each of fresh blood samples were collected through the ear vein from a male and a female (two rabbits) per replicate (totalling six per treatment). A subsample of $5 \mathrm{ml}$ was put into well labelled sterilized bottles containing Ethylenediamine tetra-acetic acid (EDTA) for haematological examinations $\mathrm{Hb}$ concentration (g/dl), RBCs (106/mm3), WBCs (106/mm3) count). Another $5 \mathrm{ml}$ was collected into plain vacumtainers (without anticoagulant) and centrifuged at $3000 \mathrm{rpm}$ for 15 minutes then used for the serum lipid profile determination based on methods described by Baker et al. (1998).Two rabbits were selected per replicate (1 male and 1 female), killed and the carcasses cut into parts with the breast meat used to determine the meat lipid profile according to method of Rahman et al., (2011).

\section{Statistical Analysis}

Data from this experiment were subjected to one-way analysis (ANOVA) for 3x2 factorial arrangement in a completely randomized design. Means were compared using the Least Significant Difference (LSD) at 5\% probability as outlined by Obi (1990). The SAS computer software package (SAS, 2000) was used for all statistical analysis.

\section{Results and Discussion}

The result of composition of the PSW as presented in table 1 indicate that it has less fat content therefore could be advantageous on weight reduction as well as enhance lean meat quality in rabbit. Pumpkin stem waste is however rich in other nutrients such as fibre (26.65\%) followed by protein $(14.03 \%)$. The rabbit needs of the fibre is to drive digested feed through the digestive tract and divide digested food/faeces into small portions. Fibre is also the best source of energy for bacteria living in the caecum where it is converted into volatile fatty acids. Fibre also protects against metabolic conditions such as hypercholesterolemia and diabetes mellitus through cleansing of the digestive tract, and removal of potential carcinogens from the body. Fibre content is generally evaluated on the basis of crude fibre. 
Table 1: Proximate Composition of Pumpkin Stem Waste

\begin{tabular}{ll}
\hline Parameters & Composition $(\%)$ \\
\hline Dry matter & 91.10 \\
Crude protein & 14.03 \\
Crude fat & 2.05 \\
Crude fibre & 26.65 \\
Ash & 13.01 \\
Nitrogen free extract & 44.26 \\
\hline
\end{tabular}

For growing rabbits a $13 \%$ to $14 \%$ crude fibre in the diet seems satisfactory (Coudert et al., 1986) and prevents the absorption of excess cholesterol. The mineral content of the sample indicated that Phosphorus and Potassium are the most abundant minerals followed by iron .Other minerals that were present in the sample in trace concentration include $\mathrm{Mg}$ and $\mathrm{Na}$. These levels of macro and micro nutrient available indicate that the Pumpkin stem is fit for rabbit dietary consumption. For instance, Phosphorus and potassium has been reported as an essential mineral which plays important role in formation of bones while Iron is reported of binding oxygen in haemoglobin thereby expanding red blood cell mass. Vitamins profile as presented in Table 2 indicate that PSW is rich in vitamins especially vitamin $C$ (ascorbic acid). Vitamin $C$ is an antioxidant which helps to protect the body against cancer and also strengthens the immune system (Nwanna and Oboh, 2007). Ezekwe and Obidoa (2001) also observed that increased in ascorbic acid in diet generally increase antioxidant activity in animal. This confers on PSW the possibility of enhancing absorption of non-heme iron. In addition, the phyto-chemical constituents (tannins, flavonoids, saponins,) of Pumpkin stem (Table 2), could boost antioxidant activity leading to significant reduction in lipid peroxidation in the rabbit fed pumpkin based diets. Similar report had earlier been made for rat (Haddad et al., 1999).These antioxidants is also known to improve resistance to heat stress (Liu et al., 2011).

Haematological profile of rabbits in this study are presented in table 3. Values obtained indicated significant increases $(\mathrm{P}<0.05)$ in $\mathrm{Hb}, \mathrm{PCV}$ and $\mathrm{RBC}$ with increasing level of dietary pumpkin stem waste. WBC and MCHC values however, indicated no significant dietary treatment effect $(\mathrm{P}>0.05)$. This implies that dietary levels of pumpkin stem waste used in this study had no toxic effect on the health status of the rabbits. All the haematological parameters $(\mathrm{Hb}, \mathrm{PCV}, \mathrm{WBC}, \mathrm{RBC}, \mathrm{MCH}, \mathrm{MCHC}$ and $\mathrm{MCV})$ were within the normal range reported by Baker et al. (1998). The haematological values obtained suggests that the pumpkin stem waste might contain more blood forming factors or may have induced the rabbits' cells to form more blood than the control diet. For instance, vitamin $\mathrm{C}$ in pumpkin stem is known to be involved in maturation of erythrocytes for maintenance of normal blood haematology (Olomu, 1995). Similar report by Otitiju et al., (2014) indicated 
that fluted pumpkin is rich in vitamin $\mathrm{B}_{12}$ and Iron which play key roles in red blood cell and haemoglobin formation. In addition, the antinutrients in PSW appears to cause no blood constituents. The result of this study corroborate Nworgu et al. (2008) who reported significant improvement in haematological parameters of rabbits fed pumpkin leaf extract. Generally, blood parameters are important in assessing quality and suitability of feed ingredients in farm animals (Maxwell et al., 1990).

Diet by sex interaction was significant $(\mathrm{P}<0.05)$ in packed cell volume (PCV). The male rabbit recorded higher PCV value compared to the female rabbits. This implies that the male rabbits may have utilized the rich nutrients; vitamins, minerals and high protein content of PSW slightly more efficiently than the female rabbits. Hence, the increased PCV level.

Table 2: Vitamins and Mineral Composition of Pumpkin Stem Waste (PSW)

\begin{tabular}{|l|r|}
\hline \multicolumn{1}{|c|}{ Parameters } & Composition \\
Vitamin A & 7.75 \\
Vitamin B & 6.75 \\
Vitamin C & 78.80 \\
Phosphorus & 116.50 \\
Potassium & 21.11 \\
Sodium & 1.65 \\
Magnesium & 1.67 \\
Iron & 7.82 \\
Glycosides & 0.023 \\
Flavonoids & 1.31 \\
Tannins & 0.46 \\
Saponins & 0.92 \\
\hline
\end{tabular}

Table 3: Effect of pumpkin stem waste and sex on haematological indices of rabbits

\begin{tabular}{|c|c|c|c|c|c|c|c|}
\hline $\begin{array}{l}\text { Dietary level of } \\
\text { PSW }\end{array}$ & $\begin{array}{l}\mathrm{Hb} \\
(\mathrm{g} / \mathrm{dl})\end{array}$ & $\begin{array}{l}\mathrm{PCV} \\
(\%)\end{array}$ & $\begin{array}{l}\text { WBC } \\
\left(\times 10^{9} /\right. \\
\left.\mathrm{mm}^{3}\right)\end{array}$ & $\begin{array}{l}\text { RBC } \\
\left(\times 10^{6} /\right. \\
\left.\mathrm{mm}^{3}\right)\end{array}$ & $\begin{array}{l}\mathrm{MCH} \\
\text { (pg/cell) }\end{array}$ & $\begin{array}{l}\text { MCHC } \\
(\%)\end{array}$ & $\begin{array}{l}\mathrm{MCV} \\
\left(\mathrm{mm}^{3}\right)\end{array}$ \\
\hline $0 \%\left(\mathrm{D}_{1}\right)$ & $12.2^{\mathrm{c}}$ & $36.0^{c}$ & 7.18 & $5.37^{\mathrm{c}}$ & $22.71^{\mathrm{a}}$ & 33.6 & $67.04^{\mathrm{a}}$ \\
\hline $5 \%\left(\mathrm{D}_{2}\right)$ & $13.5^{\mathrm{b}}$ & $40.2^{\mathrm{b}}$ & 7.30 & $6.40^{\mathrm{b}}$ & $21.09^{b}$ & 33.6 & $63.12^{\mathrm{b}}$ \\
\hline $10 \%\left(\mathrm{D}_{3}\right)$ & $15.5^{\mathrm{a}}$ & $45.5^{\mathrm{a}}$ & 7.33 & $7.42^{\mathrm{a}}$ & $20.89^{b}$ & 34.1 & $61.32^{c}$ \\
\hline SEM & 0.28 & 0.87 & 0.87 & 0.17 & 0.16 & 0.23 & 0.60 \\
\hline \multicolumn{8}{|l|}{ Sex: } \\
\hline Male & 13.86 & $41.00^{\mathrm{a}}$ & 6.97 & 6.53 & 21.16 & 33.77 & 62.96 \\
\hline Female & 13.60 & $40.10^{b}$ & 7.66 & 6.54 & 20.93 & 33.71 & 60.40 \\
\hline SEM & 0.41 & 0.29 & 0.36 & 0.27 & 0.72 & 0.01 & 2.10 \\
\hline $\begin{array}{l}\text { Diet by sex } \\
\text { interaction }\end{array}$ & NS & & NS & NS & NS & NS & NS \\
\hline
\end{tabular}




\section{Serum Lipid Profile}

Table 3 shows the values obtained for total cholesterol (TC), triglycerides (TG), high density lipoproteins (HDL), low density lipoproteins (LDL) and very low density lipoproteins (VLDL). Rabbits offered the control diet $\left(\mathrm{D}_{1}\right)$ had significantly $(\mathrm{p}<0.05)$ higher values of TC, TG, LDL and VLDL while rabbits fed diet $\mathrm{D}_{3}$ recorded the lowest values for TC, TG, LDL,VLDL and significantly higher value of HDL. Increased level of TC, TG, and LDL with decreased level of HDL have been implicated in development of chronic artery disease by Durrington et al. (1988) and Lamendala (2000). Since the rabbits fed diets $\mathrm{D}_{2}$ and $\mathrm{D}_{3}$ recorded lower values for TC, TG, LDL, VLDL even as HDL values increased with increasing pumpkin stem, it strongly suggest the hypocholesterolamic effect of pumpkin stem waste in the diet. This is also in agreement with results reported on rats by Adaramoye et al., (2007). Fluted pumpkin is apparently a good source of antioxidant such as flavonoids and Vitamin $\mathrm{C}$ which could reduce serum levels of total cholesterol and low density lipoprotein concentrations (Kayode and Kayode, 2011). Similar cholesterol- depressing effects on rats due to antioxidant (ascorbic acid) and phytochemical such as saponins, tanins, and flavonoids in Vernonia amygdalina has been observed by Ezekwe and Obidoa (2001). Probably, the mechanism of this hypolipidaemic activity involves inhibition of absorption of dietary cholesterol in the intestine or its production by the liver. Another important factor that could have contributed to reducing blood cholesterol is the high fibre content of the PSW diets. Gates (1984) reported that dietary fibre contributes to lowering blood cholesterol levels aside from decreased intake of saturated fat and cholesterol that occurs during high intake of fibres. Diets by sex interaction show significant $(\mathrm{P}<0.05)$ decrease of TG, LDL, VLDL and increase of HDL in male rabbits than their female counterparts. This suggest efficient utilization of the PSW based diets by the males compared to their female counterparts.

Table 4: Effect of pumpkin stem waste and sex on serum lipids profile of rabbit

\begin{tabular}{llllll}
\hline $\begin{array}{l}\text { Dietary level } \\
\text { of pumpkin } \\
\text { stem }\end{array}$ & $\begin{array}{l}\text { Total } \\
\text { cholesterol } \\
(\mathrm{mmol} / \mathrm{l})\end{array}$ & $\begin{array}{l}\text { Triglyceride } \\
(\mathrm{mmol} / \mathrm{l})\end{array}$ & $\begin{array}{l}\text { High density } \\
\text { lipoprotein } \\
(\mathrm{mmol} / \mathrm{l})\end{array}$ & $\begin{array}{l}\text { Low density } \\
\text { lipoprotein } \\
(\mathrm{mmol} / \mathrm{l})\end{array}$ & $\begin{array}{l}\text { Very low density } \\
\text { lipoprotein }(\mathrm{mmol} / \mathrm{l}\end{array}$ \\
\hline $0 \%\left(\mathrm{D}_{1}\right)$ & $2.01^{\mathrm{a}}$ & $1.76^{\mathrm{a}}$ & $0.39^{\mathrm{c}}$ & $1.26^{\mathrm{a}}$ & $0.35^{\mathrm{a}}$ \\
$5 \%\left(\mathrm{D}_{2}\right)$ & $1.86^{\mathrm{b}}$ & $1.66^{\mathrm{b}}$ & $0.47^{\mathrm{b}}$ & $1.06^{\mathrm{b}}$ & $0.33^{\mathrm{b}}$ \\
$10 \%\left(\mathrm{D}_{3}\right)$ & $1.83^{\mathrm{b}}$ & $1.64^{\mathrm{b}}$ & $0.53^{\mathrm{a}}$ & $0.98^{\mathrm{c}}$ & $0.32^{\mathrm{c}}$ \\
SEM & 0.01 & 0.01 & 0.01 & 0.01 & 0.001
\end{tabular}

Sex:

Male

1.88

$1.67^{\mathrm{b}}$

$0.48^{\mathrm{a}}$

$1.06^{\mathrm{b}}$

$0.33^{\mathrm{b}}$

Female

1.91

$1.71^{\mathrm{a}}$

$0.45^{\mathrm{b}}$

$1.14^{\mathrm{a}}$

$0.34^{\mathrm{a}}$

SEM

0.01

0.01

0.01

0.02

0.001 


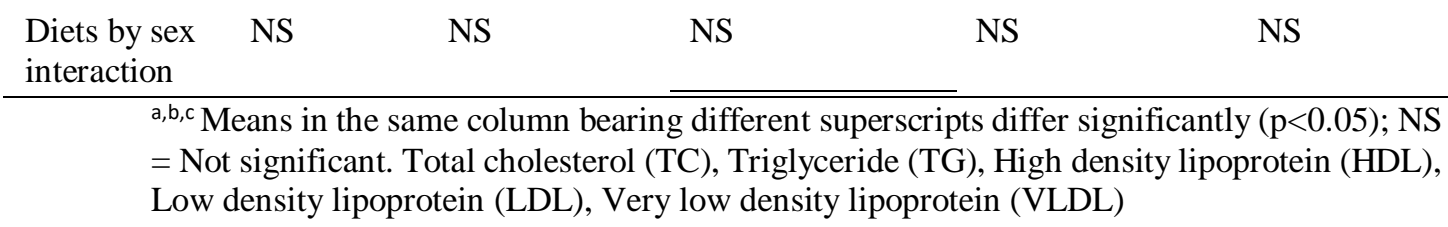

\section{Meat Lipid Profile}

The meat lipid profile obtained for rabbits fed various levels of pumpkin stem waste are presented in table 5.

Table 5: Effect of Pumpkin Stem Waste and sex on meat lipid profile of rabbit

\begin{tabular}{|c|c|c|c|c|c|}
\hline $\begin{array}{l}\text { Level of bitter } \\
\text { leaf inclusion }\end{array}$ & $\begin{array}{l}\text { Tot.choles- } \\
\text { terol (TC) } \\
(\mathrm{mg} / 100 \mathrm{~g})\end{array}$ & $\begin{array}{l}\text { Triglyceride } \\
\text { (TG) } \\
(\mathrm{mg} / 100 \mathrm{~g})\end{array}$ & $\begin{array}{l}\text { High density } \\
\text { lipoprotein(HDL) } \\
\text { (mg/100g) }\end{array}$ & $\begin{array}{l}\text { Low density } \\
\text { lipoprotein(LDL) } \\
(\mathrm{mg} / 100 \mathrm{~g})\end{array}$ & $\begin{array}{l}\text { Very low } \\
\text { density } \\
\text { lipoprotein }\end{array}$ \\
\hline $0 \%\left(\mathrm{D}_{1}\right)$ & $57.33^{\mathrm{a}}$ & $102.35^{\mathrm{a}}$ & $10.92^{\mathrm{c}}$ & $37.05^{\mathrm{a}}$ & $8.58^{\mathrm{a}}$ \\
\hline $5 \%\left(\mathrm{D}_{2}\right)$ & $53.43^{\mathrm{b}}$ & $97.9^{\mathrm{b}}$ & $15.99^{b}$ & $67.86^{\mathrm{b}}$ & $8.56^{\mathrm{ab}}$ \\
\hline $10 \%\left(\mathrm{D}_{3}\right)$ & $51.48^{\mathrm{c}}$ & $91.67^{\mathrm{c}}$ & $17.55^{\mathrm{a}}$ & $64.35^{\mathrm{c}}$ & $8.19^{c}$ \\
\hline SEM & 0.01 & 0.01 & 0.10 & 0.01 & 0.01 \\
\hline Sex: & & & & & \\
\hline Male & $53.04^{\mathrm{b}}$ & $96.12^{\mathrm{b}}$ & $14.82^{\mathrm{a}}$ & $29.25^{\mathrm{b}}$ & $8.19^{b}$ \\
\hline Female & $54.99^{\mathrm{a}}$ & $98.79^{a}$ & $14.04^{\mathrm{b}}$ & $31.59^{\mathrm{a}}$ & $8.97^{\mathrm{a}}$ \\
\hline SEM & 0.01 & 0.01 & 0.01 & 0.01 & 0.02 \\
\hline $\begin{array}{l}\text { Diet and sex } \\
\text { interaction }\end{array}$ & NS & NS & NS & NS & NS \\
\hline
\end{tabular}

Results showed significant $(\mathrm{P}<0.05)$ increase in $\mathrm{HDL}$ and declining values of TC, TG, LDL VLDL as dietary level of pumpkin stem waste increased. This suggests hypolipidaemic potential of pumpkin stem waste attributable to its antioxidant, vitamin $\mathrm{C}$ and flavonoid dietary contents. This result corroborates Adaramoye et al., (2007) who made similar observation in rats fed pumpkin extracts. Another contributing factor to the cholesterol values reduction could probably be the high fibre content of diets $\mathrm{D}_{2}$ and $\mathrm{D}_{3}$. Arietta et al. (2005) reported that dietary fibre decreased cholesterol intake and absorption efficiency in animals. Significant increase in HDL could probably be caused by poly unsaturated fatty acid in pumpkin (Abeywardena, 2003). It has been reported that Telfairia occidentals (pumpkin) possesses high levels of essential fatty acids such as linoleic and linolenic which have hypolipidemic effect (Djousse et al., 2001). This could have a strong influence on meat lipid composition because monogastrics such as rabbit are directly influenced by dietary composition (Oliver et al., 1997). Wilson et al. (1988) indicated that particles of HDL prevents coronary artery disease by serving as transport particles for excess cholesterol to the liver where it is converted into bile acids and excreted. This implies that supplementing rabbit diets with pumpkin stem 
waste could result in cholesterol reduction of meat. Result also indicated that diets by sex interaction was significant $(\mathrm{P}<0.05)$ in $\mathrm{TC}, \mathrm{TG}, \mathrm{LDL}, \mathrm{VLDL}$ and HDL. The male rabbits recorded significantly $(\mathrm{P}<0.05)$ lower values for $\mathrm{TC}$, TG, LDL and VLDL but higher for HDL compared to their female counterparts. This implies higher intake of PSW (hypolipidaemic) by male rabbits relative to the female rabbits.

\section{Conclusion}

In view of the result obtained, it is clear that dietary PSW effect increase in $\mathrm{Hb}, \mathrm{PCV}, \mathrm{RBC}$ as well as HDL in serum and meat while decreasing TC, LDL, TG and VLDL in rabbit's meat and serum. Diet by sex interaction explicitly showed that male rabbits performed better than their female counterparts in all the blood and meat lipid parameters assessed. These results reveal that pumpkin stem waste is both hypolipidaemic and hematopoietic.

\section{References:}

1. Abeywardena, M. Y. (2003). Dietary fats carbohydrates and vascular disease: srilanka perspectives. Atherosclerosis, 171: 157-161.

2. Adaramoye, O. A., Achem, J., Akintayo, O. O. \& Fafunso, M. A (2007). Hypolipidemic effect of Telfairia occidentals (Fluted pumpkin) in rats fed a cholesterol rich diet. Journal of Medicine and Food, 10(2): 330-336.

3. Arietta, M., Bennekum, V., Nguyen, D. V. Schulthess, G., Hauser, H. \& Philips, M.C. (2005). Mechanisms of cholestend-losering effects of dietary insoluble fibres: relationship with intestinal and hepatic cholesterol parameters. British Journal of Nutrition, (94), 331-337.

4. Association of official Analytical Chemists (AOAC) (1990). Official method of analysis $15^{\text {th }}$ edition USA.

5. Baker F. J, Silverton R. E, Pallister C. J (1998). Bakers and Silverton's introduction to medical laboratory technology. 7th ed. ButterworthHeine-main, Oxford. 339-73.

6. Cheeke, P. R. \& Patton, N. M. (1985). Performance of rabbit with fibre inclusion. Laboratory Animal Science, 28:167-175.

7. Coudert, P., Rouvier, R., Rochambeau, H., Rome. 1986. The rabbit husbandry, health and production. Table of contents. by. Lebas, F., FAO. http://www.fao.org/docrep/x5082e/x5082e00.htm\#contents

8. Djousse, L., Pankow, J. S., Eckfeldt, J. H., Folsom, A. R., Hopkins, P. N., Province, M. A., Hong, Y., \& Ellison, R. C. (2001). Relationship between dietary linolenic acid and coronary artery disease in the national heart lung and blood institute family heart surgery. American Journal of Nutrition, 74(5):612-9. 
9. Durrington, P. M., Hunt I., Ishola, M., A., \& Bhatna, D. (1988). Apoliprotein AL and boniel parental history in men with early onset Ischaemic heart disease. Lancet, 1:1070-1073.

10. Ekpo, J. S, Etuk, I. F. \& Solomon I. P. (2008). Influence of sex on growth and carcass traits of rabbits fed unpeeled cassava tuber meal, peeled cassava tuber meal and cassava peel meal as energy sources. Journal of Agriculture, Forestry and the social sciences, 6(1) 225-235.

11. J.S.Ekpo, N.N.Etim, G. D Eyo E.E.A.Offiong, M.D.Udo (2015) Performance and haematological Profiles of Crossbred Male Rabbits Fed Yam and Cassava by products in the Humid Tropics American Journal of Experimental Agriculture.8(2):93-98. www.sciencedomain.org

12. J S Ekpo, V.S.Udia, E.C.Ogundu, Sam I.M and G D Eyoh (2016). Carcass Traits of Crossbred rabbit bucks fed diets Supplemented with Pumpkin stem waste. European Journal of advanced Research in biological and Life Sciences. 4(3):1-7

13. Ezekwe, C. I. and Obidoa, O. (2001). Biochemical effect of vernonia amygdalina on rats liver microsomes. Nigerian Journal of Biochemistry and Molecular Biology, 16:1745-1798.

14. Gates, J. C. (1984). Basic foods. Holts, rineharrt and Winston, Canada 171:186-192.

15. Haddad EH, Berk LS, Kettering JD, Hubbard RW, Peters WR (1999) Dietary intake and biochemical, hematologic, and immune status of vegans compared with non-vegetarians. Am J Clin Nutr 70: 586S-593S

16. Iyeghe-Erakpotobor, G. T. (2010). Effect of sex and forage meals on performance of growing rubits. Proceedings $35^{\text {th }}$ conference of Nigeria society for Animal Production, 257-259 14 ${ }^{\text {th }}-17^{\text {th }}$ March, 2010.

17. Jayaweera, T.S.P; Cyril, H.W., Samarasinghe, K; Ruwandeepika, H.A.D; Wickramanayake, D. D \& Thotawanthe T. S. J, (2007).Effect of feeding velvet beans (mucuna pruriens) on the lipid profile of broiler chickens. Sabaragamuwa University Journal, 7(1):78-85

18. Kayode, A. A. A. \& Kayode, D. T. (2011). Some Medical Values of Telfairia occidentalis: A Review. American Journal of Biochemistry and Molecular Biology 1:30-38.

19. Lamendala C.(2000).Hypertriglyceridemia and low high-density lipoprotein;Risk for coronany dietary disease. Journal of Cardiovascular, 21(2): 79-90 Rural Development, 2(3):5-6.

20. Liu, H.W., Dong, X. F., Tong, J. M.\& Zhang, Q. (2011).A comparative study of growth performance and antioxidant status of rabbits when fed with or without chestnut tannins under high ambient temperature. Animal Feed Science and Technology, 164, 89-95. 
21. Lorenz, K. 1982. Improved determination of Calcium in urine with Ocresolpthalein complex one. Clinica Chimica Acta 126:327Maxwell,M.H, W.Robinson, S Spencer and C.C Maclorquodale (1990). Comparison of haematological parameters in restricted and ad libitum fed domestic fowls. British Poult.Science.31:407-413

22. Nwanna EE, Oboh G (2007) Antioxidant and hepatoprotective properties of polyphenol extracts from Telfairia occidentalis (Fluted Pumpkin) leaves on acetaminophen induced liver damage. Pak J Biol Sci 10: 2682-2687.

23. Nworgu, F. C., Onabakin, A. M. \& Obadina, T. A. (2008). Performance and haematological indices of weaned rabbits served fluted pumpkin (Telfairia occidentalis) leave extract supplement. Journal of Food, Agriculture and Environment, 6(1):128-133.

24. Obi, I.U. (1990).Statistical methods of detecting differences between treatments means .Snaap Press, Enugu.

25. Oliver, M. A., Guerrero, L., Diaz, I., Gispert, M., Pla, M. and Blasco, A. (1997).The effect of pat-enriched diets on the Perirenal fat quality and sensory characteristic of meat from rabbits. Meat Science, 47(1/2): 95- 103.

26. Olomu, J. M. (1995). Monogastric animal nutrition, principles and practice. Jackson publishing, Benin, Nigeria. 213-215.

27. Otitoju, G. T. O, Ene-Obong H. N. \& Otitoju, O. (2014). Macro and micro nutrient composition of some indigenous green leafy vegetables in South-East zone Nigeria. Food Processing and Technology, 5:11.

28. Rahman, M., Khatun, R., Tania, M., Khalil, I., Ahmed, S. \& Uddin, B. (2011). Measurement of carcass and chemical parameters for meat yield and quality analysis of rabbits: a systematic search for alternative source of complete protein. Global Veterinarian. 7(1):83-88

29. SAS Institute (2000). SAS user's guide: Statistic version 8.2. SAS Institute Inc. pp. 923

30. SLUS-AK (1994). Soil and Land Use Studies. Government print office Uyo, AkwaIbom State, soil survey staff. Key to soil Taxonomy, soil management support service (SMSS), Tech monogr. No 19. 306p.

31. Wilson, P. W.; Abbott, R. D.; \& Castelli, W. P. (1988).High density lipoprotein cholesterol and mortality. The Framingham heart study. Arteriosclerosis, 737-741. 